\title{
Rational Behavior in Cigarette Consumption: Evidence from the United States
}

\author{
Yan Song *
}

\begin{abstract}
The primary focus of this essay is to use a long time series of state cross sections for the 1955-2009 time period in the United States in order to predict cigarette consumption. This essay updates estimates of the rational addiction model of cigarette consumption obtained by Gary Becker, Michael Grossman, and Kevin Murphy in their seminal 1994 American Economic Review paper. By using two types of prices, the cigarette price and the cigarette tax, and employing a cigarette demand function, I verify that smoking is a rationally addictive form of behavior. This is based on the theory that current smoking behavior is affected by both past and future smoking behaviors. Furthermore, I estimate long-run and short-run elasticities and find that the long-run elasticity is larger than that in the short run.
\end{abstract}

[Key words] Cigarette consumption, Price, Myopic model.

\section{Introduction}

Despite overwhelming research on its damaging effects to human health, increased taxes and pricing, and an active societal campaign against it, people continue to smoke cigarettes and smoking endures as a social issue. Although some would attempt to explain this phenomenon through a myopic model of behavior which impies that currect consumption is only affected by past consumption. However, I will argue that a rational behavior model, which emphasizes that both the future price and past consumption will affect current consumption, better accounts for this human activity.

In one of the more acclaimed studies, Becker et al. (1994), an empirical analysis related to cigarette demand, marshal empirical evidence from 1955 to 1985 to show that cigarette demand rises as prices decline. This study concludes that cigarette smoking is explained best by the rational behavior model. In this paper, I examine whether their results can be verified by extending the data from 1954 to 2009 (Tax Burden on Tobacco). At the same time, I will apply smoking participation-Behavioral Risk Factor Surveillance System (BRFSS)-as another type of consumption, seeking to verify the rational behavior model.

Instead of the myopic theory that addictive current consumption is affected only by past consumption, Becker and M.Murphy (1988) suggest that addictive current consumption is affected by past and future consumption. The empirical estimation implemented by Becker et al. (1994) uses a rational model and a myopic model with OLS and 2 SLS methods of estimation. These two papers represent the standard model for later rational behavior research.

In the 1970s, researchers suggested that, for addictive products, the influence of past consumption on current consumption is greater than that of future consumption on current consumption. In contrast, by using cigarette consumption data, Becker et al. (1994) found that consumers behave in a rational additive manner, with past and future consumption affecting current consumption. Their paper demonstrated that higher future prices lead to

* Assistant Professor in Economics, Finance and Global Business department, William Paterson University,

New Jersey, email: songy2@wpunj.edu 
lower current consumption, indicating forward-looking behavior.

However, Gruber and Koszegi (2001) assert that the addictive rational model is valid when time preference is held constant. If time preference varies, the "policy" of addictive cigarette consumption will change. Gruber and Koszegi (2001) develop an alternative model, in which they embed in the Becker-Murphy framework the hyperbolic discounting preferences provided by Laibson (1997). Becker et al. (1994) can be a special case of the Gruber and Koszegi (2001) model. In order to achieve better estimation, Becker et al. (1994) put proper restrictions on the discount factor (from 0.7 to 0.95 ). In contrast, instead of calibrate the discount factor, Gruber and Koszegi (2001) estimate that value from the empirical data. While Gruber and Koszegi (2001) also use the high frequency monthly data on cigarette consumption, they find that the new model and new data indicate that future prices have an effect on current consumption. The results are similar to those of Becker et al. (1994).

In order to test the applicability of the rational addictive and myopic models, researchers have employed various data. Instead of the state aggregate sales data used by Becker et al. (1994), Levy (2010) applies the individual-level annual data in the National Vitality Statistics Natality Data (NHIS). He finds that while young smokers only respond to the current cigarette price, mature smokers respond to both current and expected future prices. Labeaga et al. (1999) also applies the individual-level data to the Becker et al. (1994) model. Kim (2005) applies three measurements of consumption to myopic and rational models: the proportion of smokers, per capita consumption, and the average daily cigarette consumption of smokers. Lanoie and Leclair (1998) use the Canadian data at the state level for the period from 1954 to 2009; Hu et al. (1994) analyze the data from 11 western states over the period 1967-1990; and in order to provide more intuitive explanations for addictive behavior, Suranovic et al. (1999) add the quitting cost ("frustrated or anxious or restless") and the negative effects of smoking (later appearing in an individual's life) to the model. All of these studies support the rational addictive model and reject the myopic model.

Scholars have also employed different estimation models. Because individual level data yield a distribution for disturbance exhibiting non-constant variance, economists have resorted to a two-part model: first, a logit or probit specification and, second, an ordinary least squares (OLS) model. In practice, people subject the dependent variable of the OLS regression model to a logarithmic transformation in order to stabilize non-constant error variances. Mullaphy (1998), Manning (1998), Manning and Mullaphy (2001) and Tauras (2005) have each investigated the bias associated with using log-transformed dependent variables andconclude that the price coefficients obtained from a conditional demand equation are biased when using a traditional log-transformed dependent variable.

In sum, the literature suggests that cigarettes are addictive and, furthermore, that cigarette addiction follows the rational behavior model. In this study, I use a broader data set to verify this result, extending the Becker et al. (1994) data to include the years 1954 to 2009. I employ both the myopic and the rational behavior model and include two measures of consumption: (i) per capita cigarette consumption (in millions of packages) from state level annual data from 1954 to 2009 (Tax Burden on Tobacco); and (ii), annual smoking participation (current smoking status) data from 1984 to 2009 (BRFSS). The results show that, a) smoking consumption is a rational addictive behavior and that, b) as prices decrease, consumption increases significantly, but smoking participation does not change much. The results verify that cigarette consumption follows rational addictive behavior.

\section{Empirical Work}

\subsection{Model}

Following Becker et al. (1994), we assume a concave utility function as:

$$
U\left(Y_{t}, C_{t}, C_{t-1}, e_{t}\right)
$$


Consumers maximize their infinite life time utility:

$$
\operatorname{Max} \sum_{t=1}^{\infty} \beta^{t-1} U\left(Y_{t}, C_{t}, C_{t-1}, e_{t}\right)
$$

subject to a lifecycle budget constraint

$$
\sum_{t=1}^{\infty} \beta^{t-1}\left(Y_{t}+P_{t} C_{t}\right)=A^{0}
$$

where: $Y_{t}$ is the consumption of a composite commodity in period $t$; $C_{t}$ is the number of packages of cigarettes consumed; $\beta$ is the discount factor. et represents unobserved variables affecting utility (Becker et al., 1994). These unobserved variables cause an endogenous consumption problem, the reason the two stage least square estimate method is used later. $A^{0}$ represents the current wealth. By maximizing utility, we get the first order condition.

$$
\begin{gathered}
U_{y}\left(C_{t}, C_{t-1}, Y_{t}, e_{t}\right)=\lambda \\
U_{1}\left(C_{t}, C_{t-1}, Y_{t}, e_{t}\right)+\beta U_{2}\left(C_{t+1}, C_{t}, Y_{t+1}, e_{t+1}\right)=\lambda P_{t}
\end{gathered}
$$

Rearranging the first order utility, results in the consumption equation, which is the regression equation:

$$
C_{t}=\theta C_{t-1}+\beta \theta C_{t+1}+\theta_{1} P_{t}+\theta_{2} e_{t}+\theta_{3} e_{t+1}
$$

where: $P_{t}$ is the current price of cigarettes, and $e_{t}$ and $e_{t+1}$ are "shift variables". This equation determines current cigarette consumption.

Equation (5) is the regression equation of rational addictive cigarette consumption. Equation (4) represents that marginal utility of current cigarette consumption $\left(U_{1}\right)$, plus the discounted marginal effect on the next period utility of today's consumption $\left(U_{2}\right)$, which is equal to the current price multiplied by the marginal utility of wealth (Becker et al., 1994). By concavity of $U$ we know that $\theta_{1}$ is negative. Equation (5) implies that increases in the current price decrease current consumption. If $\theta$ is positive, increases in past consumption and future consumption raise current consumption. So as past or future cigarette prices decrease, current consumption increases. In the myopic model, first-order condition does not include future utility $\left(\beta U_{2}\right)$. In equation (5) there is no future consumption effect. Therefore, the difference between rational and myopic models is that rational addictive individuals increase their current consumption as future prices are expected to fall, but myopic addictive individuals do not (Becker et al., 1994).

\subsection{Estimation Method}

Following Becker et al. (1994), I use the myopic and rational addiction models. First, I perform an OLS regression to estimate normal results. However, due to missing observations, past consumption and future consumption may be correlated to the error term. Because all of the consumption data for the regression cannot be collected, unobserved consumption included in the error term is correlated to the independent variable "past and future consumption". This endogeneity problem requires the use of two-stage least square (2SLS) estimation. Because current consumption is unrelated to past and future prices when other variables are held constant, past and future prices can be used as instruments. Moreover, since excise taxes imposed on cigarettes are important exogenous factors determining cigarette prices, excise tax rates may also be used as instruments.

Following Becker et al. (1994), the same instruments for consumption will be applied in both the myopic and rational model price equations. In this case, tax refers only to state tax. For all other equations, tax includes federal and state tax. 


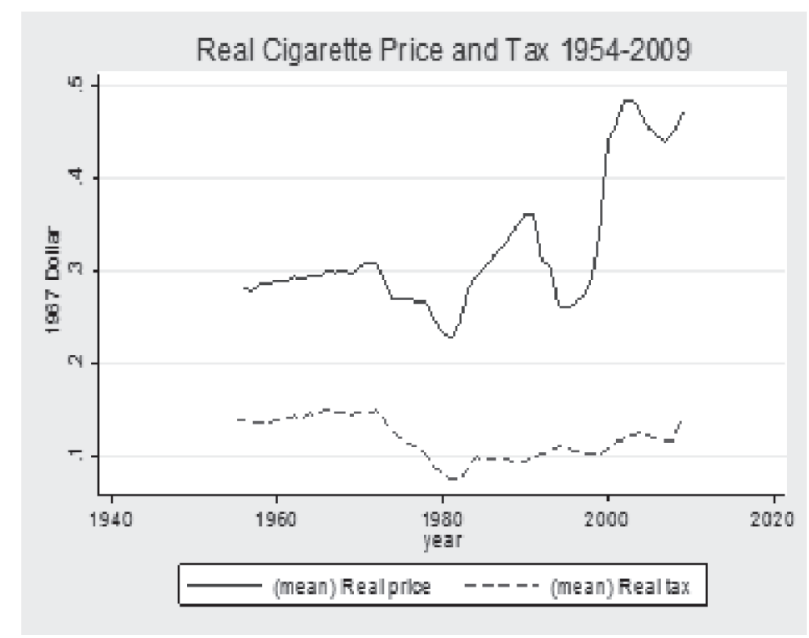

Figure 1: Real Price and Tax Data Distribution. The base period of CPI is $1967=100$. Real Tax $=($ Federal + state + county $)$ tax.

\subsection{Data}

Data for prices, taxes and consumption come from Tax Burden on Tobacco (Volume 44, 2009). Data is at the state level for the period from 1954 to 2009. The tax instrument for consumption in the myopic and rational model price equations is state tax (Table 1,2). For all others the tax instrument is (federal + state) tax. Price and tax have been adjusted for CPI increases $(1967=100)$.

Fiscal years ending June 30 are used for prices, taxes and consumption. Price data are collected in November of each year. As taxes may vary by month and year, tax is matched to price by first subtracting tax from the November price, using data from Tax Burden on Tobacco (Volume44, 2009), then adding the change in tax for month and year to the corresponding monthly price. After getting the right monthly price (including tax), we collapse it into an annual price again.

Consumption is per capita annual sales (in millions of packs) of state tax-paid cigarettes from 1954 to 2009 . The base period of CPI is $1967=100$. Real Tax $=($ Federal + state $)$ tax. Consumption is state Tax-paid Cigarette Sales (in millions of packs).

Data for smoking participation comes from the Behavioral Risk Factor Surveillance System (BRFSS). Smoking participation (current smoking status) is annual from 1984 to 2009. Smoking participation represents current smoking status. I refer to those people who smoke every day and those who smoke on some days as "current smokers"; people no longer smoking and people who never smoked are referred to as "nonsmokers".

Data for state level per capita income come from the Statistical Abstract of the United States and data are available from 1955 to 2009, so this income variable is used as an exogenous variable in the regression. The data constitute a panel of the 50 states of the U.S. over time. 


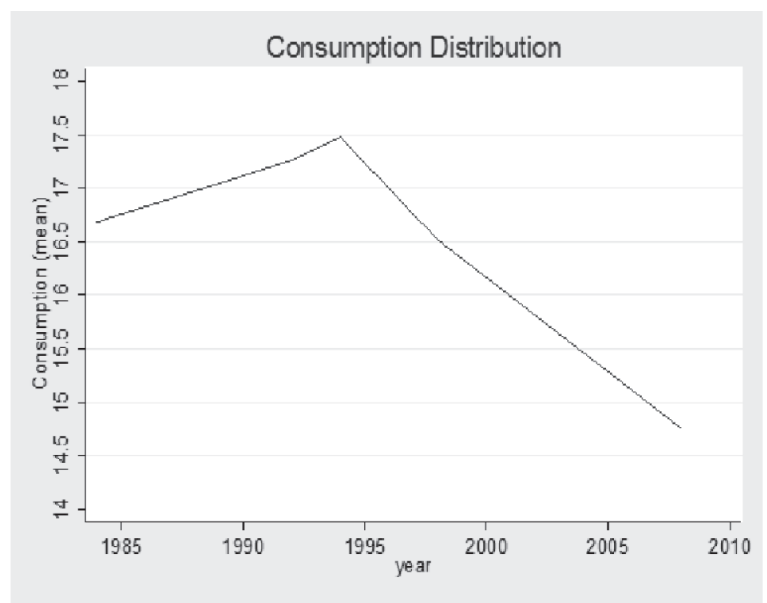

Figure 2: Daily Cigarette Consumption Distribution, 1984 - 2008.

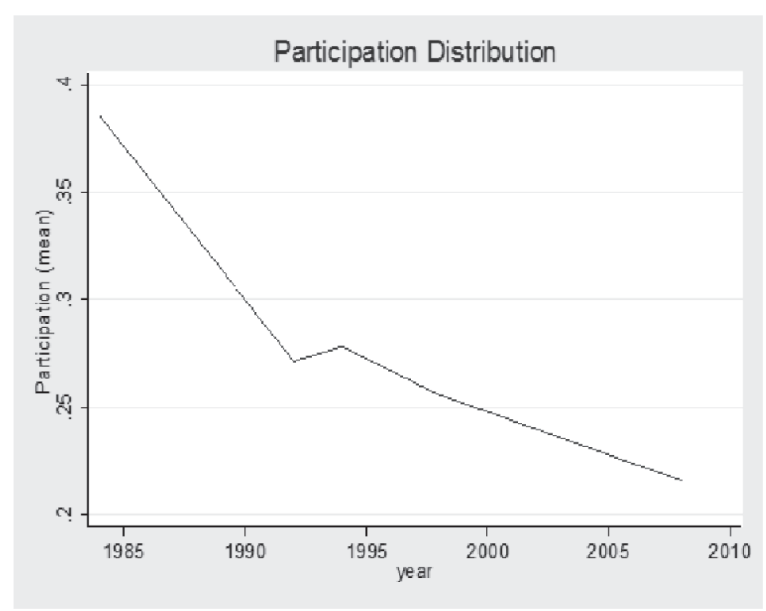

Figure 3: Participation Distribution, 1984 - 2008.

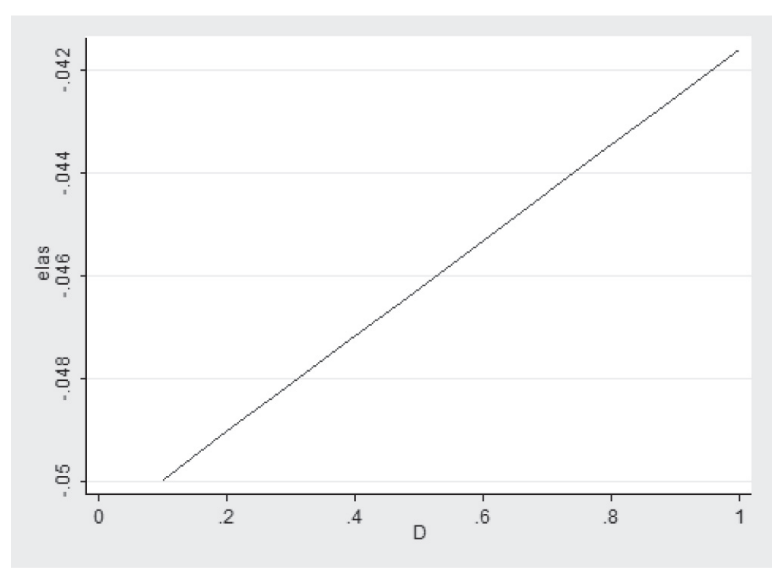

Figure 4: Elasticity Tendency for Consumption while the Discount Factor Increases by 0.1. 


\subsection{Empirical results}

According to Becker et al. (1994), if a positive past consumption coefficient is significant, holding other variables constant, then this consumption follows addictive behavior. Larger values of the past consumption coefficient $(\theta)$ mean greater degrees of addiction. From the consumption regression (Table 1), one can see that the past consumption, real cigarette price and income coefficients are significant. Therefore, cigarettes are addictive both in terms of consumption and smoking participation in the myopic model.

In Table (1), there are fewer observations in column (4) than in column (4) because the instruments in column (4) include additional second lag taxes and second lag prices. The more lags used, the more observations are lost and, therefore, there are fewer observations in the results.

Elasticity shows that, as current prices increase by 10 percent, cigarette consumption decreases by 3.5 percent in the short-run and 12 percent in the long-run; cigarette participation decreases by 0.1 percent in the short-run and 0.5 percent in the long-run.

The coefficient of past participation is great than that of consumption, indicating that smoking participation is more addictive than consumption. Insignificant elasticity suggests that price does not have a significant effect on smoking participation. This result is similar to the finding of Kim (2005) (page 56)

In the consumption equation (Table 2), the estimates of past and future consumption, real cigarette price, and income are significant. If past and future consumption positively correlate with current consumption, it indicates that the rational addictive model applies to cigarette smoking. It also indicates that myopic theory does not apply, since this theory suggests that only past consumption "reinforces" current consumption. Even though positive past and future consumption correlate significantly with current consumption, the estimated results are not very robust support for rational theory. For a rational consumer, the coefficient of future consumption is significantly positive and smaller than that of past consumption. Assuming the rate of time preference equals to the interest rate, the estimated discount factor $\beta$ (the ratio of the coefficient of future consumption to the coefficient of past consumption) should be equal to $1 /(1+r)(r$ is the estimated interest rate). The purpose of calculating the discount factor is to examine whether the estimated discount factor $(\beta)$ fits the real world or not.The estimates of consumption in Table 2 imply discount factors ranging from 0.164 to 1.23 , corresponding to interest rates from -18.7 to 509.7 percent. The wide range of discount factors suggests that interest rates are "implausible". According to Becker et al. (1994), those high interest rates can be explained by uncertainty about future prices. However the implied discount factor of 0.572 in column (4) of Table 2 (interest rate of 74 percent) is quite reasonable.

In the smoking participation equation the coefficient of future consumption is insignificant. Thus, it does not support the rational theory.

In the consumption equation, elasticity shows that as the current price increases by 10 percent, cigarette consumption decreases by 5 percent in the short-run and by 13 percent in the longrun. In Becker et al. (1994), as the current price increases by 10 percent cigarette consumption decreases by 4 percent in the short-run and by 7 percent in the long-run.

In the participation equation, elasticity shows that as the current price increases by 10 percent cigarette consumption decreases by 0.5 percent in the short-run and by 1.5 percent in the longrun.

Using tax data, past consumption, future consumption and price are all significant in the consumption equation but not in the participation equation. There is evidence of rational addictive behavior in the tax consumption equation as well as in the smoking participation OLS regression. Evidence of addictive behavior in smoking participation was found in the 2 sls model, but not in the OLS regression. Thus, the consumption equation supports rational addictive behavior, but the smoking participation data does not. This only occurs in the OLS regression, but because $C_{t+1}$ is endogenous (as is $C_{t-1}$ ), OLS estimates are biased and therefore less credible than 2SLS estimates.

Price is significant and negatively correlated to consumption in the consumption equation. However, in the smoking participation equation there was not a significant and negative relationship between price and consumption as there was in the price estimation. 
Table 1: Myopic Models (Price).

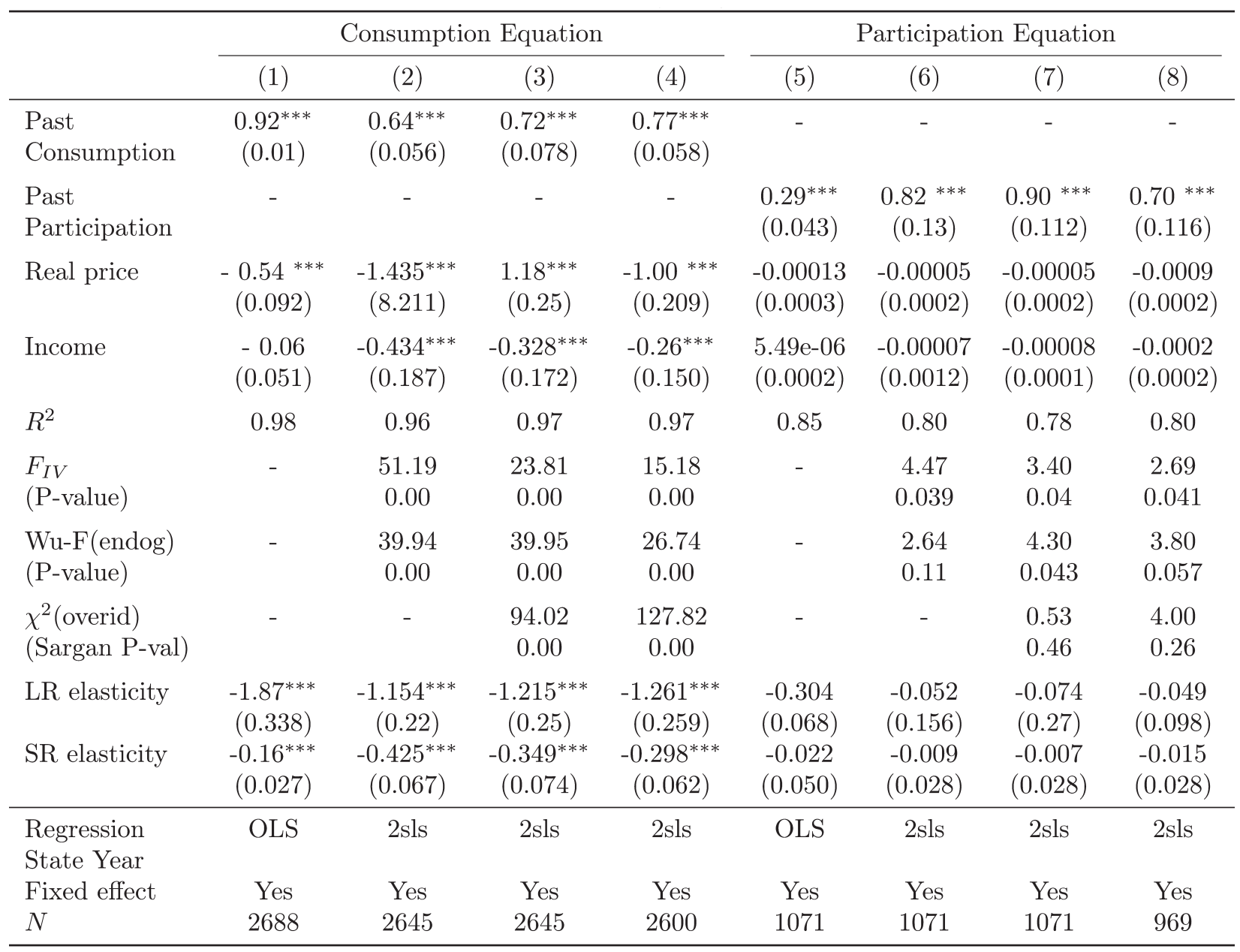

${ }^{*} p<0.05,{ }^{* *} p<0.01,{ }^{* * *} p<0.001$

Significant level at $5 \%: \mathrm{F}(1,50)=4.03: \mathrm{F}(2,50)=3.18 ; \mathrm{F}(3,50)=2.79 ; \mathrm{F}(4,50)=2.56 ; \chi^{2}(1)=3.84 ; \chi^{2}(2)=5.99 ; \chi^{2}(3)=7.81 ;$ In the consumption equation, tax is state tax. In the participation equation tax is (federal + state) tax.

First IV (2) (6) is just identifying restriction, so there is no over identifying test.

In over-identifying tests, the consumption IV (3) (4) equation results show that the null of over-identifying restriction valid is rejected ( $\mathrm{p}$-value $=0.00$ ), which means over-identifying instrument IV (3) (4) may not be valid. Similar results appear in all the over-identifying instrument tests for consumption (including price and tax, myopic and rational model). The Instruments: (in the consumption equation) in column (2) past price; in column (3) past price, current state tax, past tax; in column(4) past price, current state tax, past tax, second lag tax, second lag price.

The Instruments: (in the participation equation) in column (6) first lag tax; in column (7) one lag tax, one lead tax; in column (8) one period lag tax, first and second and third period lead tax. 
Table 2: Rational Models (Price).

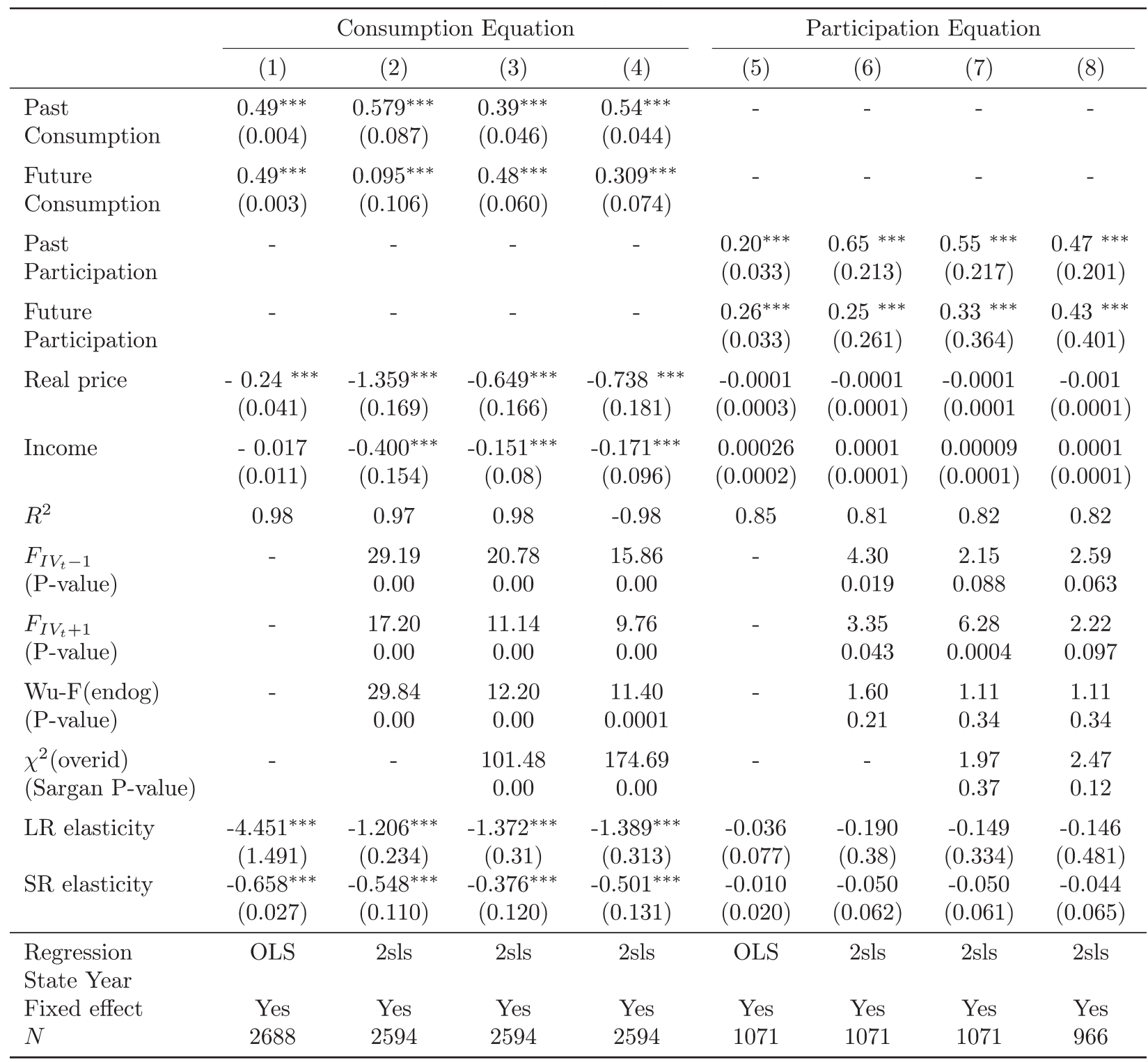

Significant level at $5 \%: \mathrm{F}(1,50)=4.03 ; \mathrm{F}(2,50)=3.18 ; \mathrm{F}(3,50)=2.79 ; \mathrm{F}(4,50)=2.56 ; \chi^{2}(1)=3.84 ; \chi^{2}(2)=5.99 ; \chi^{2}(3)=7.81$; Tax is using state tax only for consumption instrument.

In consumption IV (3) (4) equation estimates cannot reject the null of over identifying restriction being valid $(\mathrm{p}$-value $=0.00)$, which means over identifying instrument may not be valid.

Instruments: (in the consumption equation) in column (2) lag price, lead price; in column(3) lag price, lead price, current tax, lag tax; in column(4) lag price, lead price, current state tax, lag tax, lead tax.

Instruments: (in the participation equation (tax is using federal and state tax)) in column(6) past tax, second lead tax; in column(7) lag tax, second lag tax, one lead tax, second lead tax; in column (8) lag tax, second lag tax, third lead tax. 
Table 3: Myopic Models (Tax=federal+state tax $)$.

\begin{tabular}{|c|c|c|c|c|c|c|c|c|}
\hline & \multicolumn{4}{|c|}{ Consumption Equation } & \multicolumn{4}{|c|}{ Participation Equation } \\
\hline & $(1)$ & $(2)$ & $(3)$ & $(4)$ & $(5)$ & $(6)$ & (7) & $(8)$ \\
\hline $\begin{array}{l}\text { Past } \\
\text { Consumption }\end{array}$ & $\begin{array}{c}0.93^{* * *} \\
(0.01)\end{array}$ & $\begin{array}{c}0.505^{* * *} \\
(0.085)\end{array}$ & $\begin{array}{l}0.55^{* * *} \\
(0.086)\end{array}$ & $\begin{array}{l}0.55^{* * *} \\
(0.058)\end{array}$ & - & - & - & - \\
\hline $\begin{array}{l}\text { Past } \\
\text { Participation }\end{array}$ & - & - & - & - & $\begin{array}{l}0.28^{* * *} \\
(0.045)\end{array}$ & $\begin{array}{l}1.70 \\
(8.51)\end{array}$ & $\begin{array}{c}0.50 \\
(0.36)\end{array}$ & $\begin{array}{c}0.12 \\
(0.23)\end{array}$ \\
\hline $\begin{array}{l}\text { Real cigarette } \\
\text { tax }\end{array}$ & $\begin{array}{c}-0.36^{* * *} \\
(0.156)\end{array}$ & $\begin{array}{c}-1.385^{* * *} \\
(0.39)\end{array}$ & $\begin{aligned}- & 1.44^{* * *} \\
& (0.47)\end{aligned}$ & $\begin{array}{c}-1.72^{* * *} \\
(0.587)\end{array}$ & $\begin{array}{l}-0.0006 \\
(0.0003)\end{array}$ & $\begin{array}{l}{ }^{* *}-0.003 \\
(0.0077)\end{array}$ & $\begin{array}{l}-0.0004 \\
(0.0004)\end{array}$ & $\begin{array}{c}-0.0008^{* *} \\
(0.0004)\end{array}$ \\
\hline Income & $\begin{array}{l}-0.016 \\
(0.051)\end{array}$ & $\begin{array}{c}-0.471^{* * *} \\
(0.279)\end{array}$ & $\begin{array}{c}-0.446^{* * *} \\
(0.276)\end{array}$ & $\begin{array}{c}-0.48^{* * *} \\
(0.279)\end{array}$ & $\begin{array}{l}0.00005 \\
(0.0003)\end{array}$ & $\begin{array}{l}-0.00003 \\
(0.0011)\end{array}$ & $\begin{array}{c}0.0001 \\
(0.0003)\end{array}$ & $\begin{array}{c}0.0001 \\
(0.0005)\end{array}$ \\
\hline$R^{2}$ & 0.98 & 0.94 & 0.95 & -0.95 & 0.85 & 0.17 & 0.83 & 0.83 \\
\hline $\begin{array}{l}F_{I V} \\
(\mathrm{P} \text {-value })\end{array}$ & - & $\begin{array}{c}24.187 \\
0.00\end{array}$ & $\begin{array}{c}11.52 \\
0.0001\end{array}$ & $\begin{array}{l}8.28 \\
0.00\end{array}$ & - & $\begin{array}{c}0.087 \\
0.76\end{array}$ & $\begin{array}{l}1.25 \\
0.30\end{array}$ & $\begin{array}{l}1.51 \\
0.21\end{array}$ \\
\hline $\begin{array}{l}\text { Wu-F(endog) } \\
\text { (P-value) }\end{array}$ & - & $\begin{array}{l}57.75 \\
0.00\end{array}$ & $\begin{array}{c}42.09 \\
0.00\end{array}$ & $\begin{array}{c}49.43 \\
0.00\end{array}$ & - & $\begin{array}{l}0.587 \\
0.447\end{array}$ & $\begin{array}{l}0.358 \\
0.55\end{array}$ & $\begin{array}{c}0.187 \\
0.67\end{array}$ \\
\hline $\begin{array}{l}\chi^{2} \text { (overid) } \\
\text { (Sargan P-val) }\end{array}$ & - & - & $\begin{array}{c}27.33 \\
0.00\end{array}$ & $\begin{array}{c}27.39 \\
0.00\end{array}$ & - & - & $\begin{array}{l}1.41 \\
0.49\end{array}$ & $\begin{array}{l}2.65 \\
0.45\end{array}$ \\
\hline LR elasticity & $\begin{array}{c}-0.52^{* * *} \\
(0.190)\end{array}$ & $\begin{array}{c}-0.294^{* * *} \\
(0.112)\end{array}$ & $\begin{array}{c}-0.337^{* * *} \\
(0.12)\end{array}$ & $\begin{array}{c}-0.395^{* * *} \\
(0.121)\end{array}$ & $\begin{array}{c}-0.038^{* * *} \\
(0.016)\end{array}$ & $\begin{array}{c}-0.044^{* * *} \\
(0.013)\end{array}$ & $\begin{array}{c}-0.040^{* * *} \\
(0.019)\end{array}$ & $\begin{array}{c}-0.043^{* * *} \\
(0.017)\end{array}$ \\
\hline SR elasticity & $\begin{array}{c}-0.039^{* * *} \\
(0.017)\end{array}$ & $\begin{array}{c}-0.148^{* * *} \\
(0.042)\end{array}$ & $\begin{array}{c}-0.152^{* * *} \\
(0.05)\end{array}$ & $\begin{array}{c}-0.178^{* * *} \\
(0.061)\end{array}$ & $\begin{array}{c}-0.027^{* *} \\
(0.012)\end{array}$ & $\begin{array}{c}-0.119 \\
(0.368)\end{array}$ & $\begin{array}{l}-0.020 \\
(0.018)\end{array}$ & $\begin{array}{c}-0.038^{* *} \\
(0.016)\end{array}$ \\
\hline $\begin{array}{l}\text { Regression } \\
\text { State Year }\end{array}$ & OLS & 2 sls & 2 sls & 2 sls & OLS & $2 \mathrm{sls}$ & 2 sls & 2 sls \\
\hline $\begin{array}{l}\text { Fixed effect } \\
N\end{array}$ & $\begin{array}{c}\text { Yes } \\
2689\end{array}$ & $\begin{array}{c}\text { Yes } \\
2688\end{array}$ & $\begin{array}{c}\text { Yes } \\
2637\end{array}$ & $\begin{array}{c}\text { Yes } \\
2600\end{array}$ & $\begin{array}{c}\text { Yes } \\
1071\end{array}$ & $\begin{array}{c}\text { Yes } \\
1071\end{array}$ & $\begin{array}{c}\text { Yes } \\
1020\end{array}$ & $\begin{array}{l}\text { Yes } \\
969\end{array}$ \\
\hline
\end{tabular}

Significant level at $5 \%: \mathrm{F}(1,50)=4.03 ; \mathrm{F}(2,50)=3.18 ; \mathrm{F}(3,50)=2.79 ; \mathrm{F}(4,50)=2.56 ; \chi^{2}(1)=3.84 ; \chi^{2}(2)=5.99 ; \chi^{2}(3)=7.81$;

Instruments: (in consumption equation) in column (2) lag tax; in column (3) lag tax, lead tax; in column (4) lag tax, first, second and third lead tax;

Instruments: (in participation equation) in column (6) second lag tax; in column (7) lag tax, lead tax, second lead tax; in column (8) lag tax, first and second and third lead tax. 
Table 4: Rational Models $($ Tax $=$ federal + state tax $)$.

\begin{tabular}{|c|c|c|c|c|c|c|c|c|}
\hline & \multicolumn{4}{|c|}{ Consumption Equation } & \multicolumn{4}{|c|}{ Participation Equation } \\
\hline & (1) & $(2)$ & $(3)$ & (4) & $(5)$ & (6) & $(7)$ & (8) \\
\hline $\begin{array}{l}\text { Past } \\
\text { Consumption }\end{array}$ & $\begin{array}{l}0.49^{* * *} \\
(0.004)\end{array}$ & $\begin{array}{c}0.949^{* * *} \\
(0.383)\end{array}$ & $\begin{array}{l}0.35^{* * *} \\
(0.081)\end{array}$ & $\begin{array}{l}0.54^{* * *} \\
(0.075)\end{array}$ & - & - & - & - \\
\hline $\begin{array}{l}\text { Future } \\
\text { Consumption }\end{array}$ & $\begin{array}{l}0.49^{* * *} \\
(0.004)\end{array}$ & $\begin{array}{l}-0.99 \\
(0.738)\end{array}$ & $\begin{array}{l}0.42^{* * *} \\
(0.136)\end{array}$ & $\begin{array}{c}0.154^{* * *} \\
(0.044)\end{array}$ & - & - & - & - \\
\hline $\begin{array}{l}\text { Past } \\
\text { Participation }\end{array}$ & - & - & - & - & $\begin{array}{l}0.20^{* * *} \\
(0.033)\end{array}$ & $\begin{array}{c}0.44 \\
(0.456)\end{array}$ & $\begin{array}{c}0.31 \\
(0.34)\end{array}$ & $\begin{array}{c}0.42 \\
(0.467)\end{array}$ \\
\hline $\begin{array}{l}\text { Future } \\
\text { Participation }\end{array}$ & - & - & - & - & $\begin{array}{l}0.25^{* * *} \\
(0.035)\end{array}$ & $\begin{array}{c}0.35 \\
(0.33)\end{array}$ & $\begin{array}{c}0.20 \\
(0.42)\end{array}$ & $\begin{array}{c}0.15 \\
(0.451)\end{array}$ \\
\hline $\begin{array}{l}\text { Real cigratte } \\
\text { tax }\end{array}$ & $\begin{array}{c}-0.213^{* * *} \\
(0.06)\end{array}$ & $\begin{array}{c}-3.12^{* * *} \\
(0.724)\end{array}$ & $\begin{array}{c}-0.973^{* * *} \\
(0.473)\end{array}$ & $\begin{array}{c}-1.196^{* * *} \\
(0.416)\end{array}$ & $\begin{array}{l}-0.0005^{*} \\
(0.0003)\end{array}$ & $\begin{array}{l}-0.0002 \\
(0.0004)\end{array}$ & $\begin{array}{l}-0.0004^{*} \\
(0.0002)\end{array}$ & $\begin{array}{l}-0.0003 \\
(0.0003)\end{array}$ \\
\hline Income & $\begin{array}{c}-0.036 * \\
(0.019)\end{array}$ & $\begin{array}{l}-1.099 \\
(0.888)\end{array}$ & $\begin{array}{l}-0.21 \\
(0.146)\end{array}$ & $\begin{array}{l}-0.371 \\
(0.198)\end{array}$ & $\begin{array}{l}0.00005 \\
(0.0003)\end{array}$ & $\begin{array}{l}0.00009 \\
(0.0002)\end{array}$ & $\begin{array}{l}0.00007 \\
(0.0003)\end{array}$ & $\begin{array}{l}0.00008 \\
(0.0002)\end{array}$ \\
\hline$R^{2}$ & 0.99 & 0.76 & 0.98 & 0.97 & 0.85 & 0.84 & 0.85 & 0.84 \\
\hline $\begin{array}{l}F_{I V_{t}-1} \\
\text { (P-value) }\end{array}$ & - & $\begin{array}{c}11.52 \\
0.0001\end{array}$ & $\begin{array}{c}10.55 \\
0.00\end{array}$ & $\begin{array}{c}10.71 \\
0.00\end{array}$ & - & $\begin{array}{c}2.32 \\
0.109\end{array}$ & $\begin{array}{l}1.31 \\
0.28\end{array}$ & $\begin{array}{l}1.72 \\
0.18\end{array}$ \\
\hline $\begin{array}{l}F_{I V_{t}+1} \\
\text { (P-value) }\end{array}$ & - & $\begin{array}{c}3.79 \\
0.029\end{array}$ & $\begin{array}{c}12.45 \\
0.00\end{array}$ & $\begin{array}{l}7.26 \\
0.00\end{array}$ & - & $\begin{array}{l}1.04 \\
0.36\end{array}$ & $\begin{array}{c}2.98 \\
0.028\end{array}$ & $\begin{array}{l}2.25 \\
0.09\end{array}$ \\
\hline $\begin{array}{l}\text { Wu-F(endog) } \\
\text { (P-value) }\end{array}$ & - & $\begin{array}{c}19.78 \\
0.00\end{array}$ & $\begin{array}{c}20.16 \\
0.00\end{array}$ & $\begin{array}{c}31.73 \\
0.0001\end{array}$ & - & $\begin{array}{l}0.34 \\
0.71\end{array}$ & $\begin{array}{c}0.056 \\
0.95\end{array}$ & $\begin{array}{l}0.13 \\
0.88\end{array}$ \\
\hline $\begin{array}{l}\chi^{2} \text { (overid) } \\
(\text { Sargan } P \text {-val })\end{array}$ & - & - & $\begin{array}{c}53.07 \\
0.00\end{array}$ & $\begin{array}{c}74.96 \\
0.00\end{array}$ & - & - & $\begin{array}{l}1.97 \\
0.37\end{array}$ & $\begin{array}{l}1.21 \\
0.27\end{array}$ \\
\hline LR elasticity & $\begin{array}{c}-1.691^{* * *} \\
(0.626)\end{array}$ & $\begin{array}{c}-0.316^{* * *} \\
(0.121)\end{array}$ & $\begin{array}{c}-0.438^{* * *} \\
(0.120)\end{array}$ & $\begin{array}{c}-0.408^{* * *} \\
(0.124)\end{array}$ & $\begin{array}{l}-0.040^{*} \\
(0.023)\end{array}$ & $\begin{array}{l}-0.040 \\
(0.051)\end{array}$ & $\begin{array}{l}-0.038 \\
(0.026)\end{array}$ & $\begin{array}{l}-0.035 \\
(0.028)\end{array}$ \\
\hline SR elasticity & $\begin{array}{c}-0.641^{* * *} \\
(0.182)\end{array}$ & $\begin{array}{c}-0.494^{* * *} \\
(0.185)\end{array}$ & $\begin{array}{c}-0.366^{* *} \\
(0.23)\end{array}$ & $\begin{array}{c}-0.493^{* * *} \\
(0.199)\end{array}$ & $\begin{array}{l}-0.010 \\
(0.007)\end{array}$ & $\begin{array}{l}-0.015 \\
(0.044)\end{array}$ & $\begin{array}{l}-0.014 \\
(0.021)\end{array}$ & $\begin{array}{l}-0.016 \\
(0.030)\end{array}$ \\
\hline $\begin{array}{l}\text { Regression } \\
\text { State Year }\end{array}$ & OLS & 2 sls & 2sls & 2 sls & OLS & 2 sls & 2sls & 2sls \\
\hline Fixed effect & Yes & Yes & Yes & Yes & Yes & Yes & Yes & Yes \\
\hline$N$ & 2638 & 2637 & 2535 & 2492 & 1071 & 1071 & 1071 & 1017 \\
\hline
\end{tabular}

All tests are added robust test (cluster). Tax is using state tax only for consumption instrument.

In consumption IV (3) (4) equation estimates cannot reject the null of over identifying restriction being valid $(\mathrm{p}$-value $=0.00)$, which means over identifying instrument may not be valid.

Instrument: (in consumption equation) in column (2) lag tax, lead tax; in column (3) lag tax, second and third lead tax; in column (4) lag tax, second lag tax, first and second and third lead tax;

Instrument: (in participation equation) in column (6) lag tax, second lead tax. In column (7) lag tax, second lag tax, first and second lead tax; in column (8) lag tax, second lag tax, second lead tax. 
Long-run price elasticity was smaller in both the tax consumption and tax smoking-participation equations than in the price regression.

\section{Robustness test.}

In order to check whether the estimation is correct, the regression results were compared to Becker et al. (1994) results from the same time period. The original data of Becker et al. (1994) were consumption, price and income, excluding Ldtax, sdtimp, sdtexpn. It shows that the price coefficient is similar.

Comparing the results to the Becker et al. (1994) data (Table 5), the 2sls price coefficient is around 2.7 and the data price coefficient is 2.9 , resulting in a price coefficient close to Becker et al. (1994). In my data, the income coefficient is somewhat greater than that of the BGM Becker et al. (1994) data. One possible reason is that the original income data was recently adjusted by an updated measurement, so that the income data collected now is different from that of a few years ago. The above results suggest that the data used here are similar to the data used by Becker et al. (1994) and no bias estimation was caused by the data.

Finally, I compare the real price and income coefficients from the period before (and including) 1985 to the period after 1985. If the coefficients are significantly different, it will suggest that the characteristics of the data before and after 1985 are different. The Wald test shows that the two real price coefficients and the income coefficients are significantly different. Ordinarily, income has a positive effect on consumption, but some later period income coefficient become negative. This difference, however, does not invalidate the conclusions. As more information has become available about the harmful effects of smoking since 1980s, the relationship between income and smoking has switched from positive to negative: instead of a normal good, cigarette consumption has become an inferior good.

This conclusion is consistent with the finding from existing literature. Both Pierce et al. (1989) and Graham (1996) find that the decline in smoking prevalence is associated with higher education and income, suggesting that the importance of the health issues was reviewed by higher socio-economic groups. Many research evidence over the countries have shown that cigarette smoking is the leading cause of preventable illness (Lopez et al., 1994). Better-educated and upper income groups tend to be less likely to smoke.

\section{Conclusion}

The results suggest two conclusions. First, smoking is a rational addictive behavior in the consumption equation. Smoking participation has a higher degree of addiction than consumption in the myopic model, but not in the rational model.

Table 5: Myopic Models of Addiction (Dependent Variable =Consumption).

\begin{tabular}{lccccc}
\hline & \multicolumn{2}{c}{ OLS } & & \multicolumn{2}{c}{ 2SLS (IV=Past price) } \\
\cline { 2 - 3 } \cline { 5 - 6 } & BGM [1994] & My data & & BGM [1994] & My data \\
\hline Past Consumption & $0.824^{* * *}$ & $0.831^{* * *}$ & & $0.519^{* * *}$ & $0.516^{* * *}$ \\
& $(0.012)$ & $(0.011)$ & & $(0.042)$ & $(0.041)$ \\
Real Price & $1.433^{* * *}$ & $-1.500^{* * *}$ & & $-2.698^{* * *}$ & $-2.920^{* * *}$ \\
Income & $(0.101)$ & $(0.105)$ & & $(0.206)$ & $(0.218)$ \\
& $0.272^{* * *}$ & $0.197^{* * *}$ & & $0.698^{* * *}$ & $0.378^{* * *}$ \\
& $(0.098)$ & $(0.082)$ & & $(0.132)$ & $(0.107)$ \\
\hline
\end{tabular}

Note: standard Error in Parentheses. 
Table 6: Rational Models of Addiction (Dependent Variable $=$ Consumption.

\begin{tabular}{lccccc}
\hline & \multicolumn{2}{c}{ OLS } & & $\begin{array}{c}\text { 2SLS (IV=Past and Future price, } \\
\text { past and current tax })\end{array}$ \\
\cline { 2 - 3 } \cline { 5 - 6 } \cline { 5 - 6 } Past Consumption & $0.489^{* * *}$ & $0.492^{* * *}$ & & $0.388^{* * *}$ & $0.404^{* * *}$ \\
& $(0.014)$ & $(0.013)$ & & $(0.050)$ & $(0.049)$ \\
Future Consumption & $0.468^{* * *}$ & $0.467^{* * *}$ & & $0.175^{* * *}$ & $0.162^{* * *}$ \\
& $(0.014)$ & $(0.014)$ & & $(0.061)$ & $(0.057)$ \\
Real Price & $0.604^{* * *}$ & $-0.651^{* * *}$ & & $-2.413^{* * *}$ & $-2.600^{* * *}$ \\
Income & $(0.080)$ & $(0.083)$ & & $(0.230)$ & $(0.233)$ \\
& $0.171^{* * *}$ & $0.102^{* * *}$ & & $0.669^{* * *}$ & $0.346^{* * *}$ \\
Price Elasticity & $(0.098)$ & $(0.062)$ & & $(0.122)$ & $(0.095)$ \\
& - & - & & $0.566^{* * *}$ & $0.578^{* * *}$ \\
& - & & & $(0.054)$ & $(0.052)$ \\
\hline
\end{tabular}

Table 7: Myopic Models of Addiction (Wald Test).

\begin{tabular}{|c|c|c|c|c|c|c|}
\hline & \multicolumn{3}{|c|}{ OLS } & \multicolumn{3}{|c|}{ 2SLS (IV=Past price) } \\
\hline & $\begin{array}{c}\text { My data } \\
(\text { Year }<=1985)\end{array}$ & $\begin{array}{c}\text { My data } \\
(\text { Year }>1985)\end{array}$ & $\begin{array}{l}\text { Wald Test } \\
\text { (P-value) }\end{array}$ & $\begin{array}{c}\text { My data } \\
(\text { Year }<=1985)\end{array}$ & $\begin{array}{c}\text { My data } \\
(\text { Year }>1985)\end{array}$ & $\begin{array}{l}\text { Wald Test } \\
\text { (P-value) }\end{array}$ \\
\hline $\begin{array}{l}\text { Past } \\
\text { Consumption }\end{array}$ & $\begin{array}{c}0.898^{* * *} \\
(0.012)\end{array}$ & $\begin{array}{c}0.887^{* * *} \\
(0.018)\end{array}$ & $\begin{array}{c}0.37 \\
(0.545)\end{array}$ & $\begin{array}{c}0.487^{* * *} \\
(0.062)\end{array}$ & $\begin{array}{c}0.685^{* * *} \\
(0.121)\end{array}$ & $\begin{array}{c}3.13 \\
(0.077)\end{array}$ \\
\hline Real Price & $\begin{aligned}-0.837^{* * *} & (0.148)\end{aligned}$ & $\begin{array}{c}-0.269^{* * *} \\
(0.086)\end{array}$ & $\begin{array}{l}16.90^{* * *} \\
(0.0001)\end{array}$ & $\begin{array}{c}-2.699^{* * *} \\
(0.411)\end{array}$ & $\begin{array}{l}-0.368 \\
(0.308)\end{array}$ & $\begin{array}{l}21.57 \\
(0.000)\end{array}$ \\
\hline Income & $\begin{array}{c}0.188^{* *} \\
(0.072)\end{array}$ & $\begin{array}{l}-0.090^{*} \\
(0.048)\end{array}$ & $\begin{array}{c}28.62^{* * *} \\
(0.000)\end{array}$ & $\begin{array}{l}0.568 * \\
(0.299)\end{array}$ & $\begin{array}{c}-0.574^{* * *} \\
(0.191)\end{array}$ & $\begin{array}{c}24.02 \\
(0.000)\end{array}$ \\
\hline
\end{tabular}

Table 8: Rational Models of Addiction (Wald Test).

\begin{tabular}{lcccccccc}
\hline & \multicolumn{3}{c}{ OLS } & & \multicolumn{3}{c}{ 2SLS } \\
\cline { 2 - 3 } \cline { 7 - 8 } & $\begin{array}{c}\text { My data } \\
(\text { Year }<=1985)\end{array}$ & $\begin{array}{c}\text { My data } \\
(\text { Year }>1985)\end{array}$ & $\begin{array}{c}\text { Wald Test } \\
(\text { P-value })\end{array}$ & $\begin{array}{c}\text { My data } \\
(\text { Year }<=1985)\end{array}$ & $\begin{array}{c}\text { My data } \\
(\text { Year }>1985)\end{array}$ & $\begin{array}{c}\text { Wald Test } \\
(\text { P-value })\end{array}$ \\
\hline Past & $0.496^{* * *}$ & $0.486^{* * *}$ & 1.85 & & $0.417^{* * *}$ & & $0.327^{* * *}$ & 0.39 \\
Consumption & $(0.004)$ & $(0.007)$ & $(0.180)$ & & $(0.067)$ & & $(0.121)$ & $(0.532)$ \\
Future & $0.481^{* * *}$ & $0.493^{* * *}$ & 2.55 & & 0.239 & & $0.551^{* * *}$ & 3.04 \\
Consumption & $(0.007)$ & $(0.004)$ & $(0.112)$ & & $(0.094)$ & & $(0.207)$ & $(0.081)$ \\
Real Price & $-0.376^{* * *}$ & $-0.125^{* * *}$ & 18.93 & & $-2.017^{* * *}$ & & -0.092 & 35.25 \\
& $(0.062)$ & $(0.039)$ & $(0.0001)$ & & $(0.304)$ & & $(0.212)$ & $(0.000)$ \\
Income & $0.070^{* * *}$ & 0.004 & 8.04 & & 0.297 & & $-0.376^{* * *}$ & 6.55 \\
& $(0.024)$ & $(0.015)$ & $(0.007)$ & & $(0.255)$ & & $(0.125)$ & $(0.011)$ \\
\hline
\end{tabular}

2SLS (IV=Past and Future price,Past and current tax) 
Second, a decline in cigarette prices significantly increases the number of cigarettes smoked in the consumption equation, but not in the smoking participation equation. These results are consistent with Evans and Farrely (1998) and $\mathrm{Hu}$ et al. (1995). A large quantities of smoking literature show that both prevalence and intensity of smoking are negatively affected by the change in cigarette prices. (IARC, 2011) Nevertheless, smoking behavior is addictive. If additive factor of nicotine plays an important role on smoking, an increase in cigarette prices would not have significant effect on quitting smoking.(Evans and Farrely, 2006; Hersch, 2000). This is the reason that the increase in prices has the significant effect on the cigarette consumption rather than that on smoking prevalence.

Long-run elasticity is greater than short run elasticity. The consumption long-run price elasticity (-1.3) is greater than Becker et al. (1994)'s finding (-0.7). This result may be due to the longer period of data. Three other variables used by Becker et al. (1994) were omitted and the Wald test shows that the parameter of price, past and future consumption, and income have been changed since 1985, so the results cannot be compared to Becker et al. (1994). One reason for using tax instead of price is to compare long-run elasticities. Since tax is just a component of price, the long-run elasticity of price is greater than that of tax. Price elasticity is more dominant than that of the tax. From the data, this result can be seen by comparing the long-run elasticities in the table. Another reason is that tax is a more exogenous variable than price. Price is an outcome variable of the supply and demand that drive the cigarette market and, as such, is endogenous. Tax rates are set by policy makers, not in response to demand conditions. Thus, a change in the disturbance does not generate a change in tax rates, but may well generate a change in prices. It can be clearly observed to be a strong instrument for consumption and participation regression. Therefore, price and tax can be used as instruments in price regression, but only tax can be used as an instrument in tax regression.

Two measures of consumption are applied because consumption (from 1954 to 2009, Tax Burden on Tobacco) and smoking participation (BRFSS) have different characteristics. Past participation has a greater influence on current participation than it does on future participation. Since participation has only two discrete choices (smoking or not smoking), past smoking affects current smoking status, but future smoking does not influence current smoking. The data show that participation is more addictive in the myopic model and not addictive in the rational model in 2 SLS (Table 1,2). Furthermore, since participation has only two discrete choices, price changes will not affect participation very much. The results clearly show that price has an insignificant effect on participation (Table 1,2). There is a discount factor restriction test in the paper of Becker et al. (1994) and Gruber and Koszegi (2001), which implies that time-preference change might affect the result of rational behavior. In the future research I will examine those tests to see how time-preference difference affects rational model consequences.

In this paper, the empirical results of consumption from differentiated tax policies among different states suggest that the higher taxes and prices could significantly reduce smoking prevalence and cigarette consumption. Similar evidence can also be found from Sloan and G.Trogdon (2004), Lewit and Coate (1982), Tauras (2004), DeCicca and McLeod (2008). The sufficient evidence implies that the tax and price policies are the effective policy tools in the control of tobacco use. In terms of pricing policy, it seems that many developing countries in Asian whose tobacco prices are relatively low should take account of attaining substantial increases in tobacco taxes and prices in the activities of tobacco control. The cigarette industry is oligopolistic, so the government can use the monetary or tax credit policy to give the cigarette producers the incentive to raise cigarette prices. Meanwhile, an expected increase in cigarette excise taxes in the future will also cause a rise in cigarette prices.

\section{References}

Becker, G. S., Grossman, M. and M.Murphy, K. (1994), 'An empirical analysis of cigarette addiction.', The American Economic Review 84(3), 396-418.

Becker, G. S. and M.Murphy, K. (1988), 'A theory of rational addiction.', Journal of Political Economy 96(4), 675-700.

DeCicca, P. and McLeod, L. (2008), 'Cigarette taxes and older adult smoking: evidence from recent large tax increases.', Journal of Health Economics 27(4), 918-929. 
Evans, W. N. and Farrely, M. C. (1998), 'The compensating behavior of smokers: taxes,tar, and nicotine.', The RAND Journal of Economics 29(3), 578-595.

Evans, W. N. and Farrely, M. C. (2006), 'Taxes, cigarette consumption, and smoking intensity.', Ameican Economic Review 96(4), 1013-1028.

Graham, H. (1996), 'Smoking prevalence among women in the european community 1950-1990.', Social Science and Medicine 43(2), 243-254.

Gruber, J. and Koszegi, B. (2001), 'Is addiction rational? theory and evidence.', Quarterly Journal of Economics 116(4), 12611303.

Hersch, J. (2000), 'Gender, income levels, and the demand for cigarettes.', Journal of Risk and Uncertainty 21(2-3), 263-282.

Hu, T. W., Ren, Q. F., Keeler, T. E. and Bartlett, J. (1995), 'The demand for cigarettes in california and behavioural risk factors.', Health Economics 4(1), 7-14.

Hu, T. W., Theodore E, K. and Sung, H. Y. (1994), 'Cigarette taxation and demand: an empirical model.', Contemporary Economic Policy 12(3), 91-101.

IARC (2011), 'Effectiveness of tax and price policies for tobacco control., IARC Handbooks of Cancer Prevention:Tobacco Control 14, 918-929.

Kim, S. (2005), 'Endogenous time preference and addiction.', Ph.D. dissertation, The City University of New York, Economics Department.

Labeaga, L. M., Theodore E, K. and Sung, H.-Y. (1999), 'A double-hurdle rational addiction model with heterogeneity: Estimating the demand for tabacco.', Journal of Econometrics 93(1), 49-72.

Laibson, D. (1997), 'Golden eggs and hyperbolic discounting,.', Quarterly Journal of Economics 111(2), 443-477.

Lanoie, P. and Leclair, P. (1998), 'Golden eggs and hyperbolic discounting,.', Economics Letters 58(1), 85-89.

Levy, M. (2010), 'An empirical analysis of biases in cigarette addiction.', working paper, Harvard University: https://pdfs. semanticscholar.org/1111/bb18869ffdc2b08d0c5222c031d55e53f718.pdf 93(1), 49-72.

Lewit, E. M. and Coate, D. (1982), 'The potential for using excise taxes to reduce smoking.', Journal of Health Economics 1(2), $121-145$.

Lopez, A. D., Collishaw, N. E. and Piha, T. (1994), 'A descriptive model of the cigarette epidemic in developed countries.', Tobacco Control 3(3), 242-247.

Manning, W. G. (1998), 'The logged dependent variable, heteroscedasticity, and the retransformation problem..', Journal of Health Economics 17(3), 283-295.

Manning, W. G. and Mullaphy, J. (2001), 'Estimating log models; to transformation or not to transform.', Journal of Health Economics 20(4), 461-494.

Mullaphy, J. (1998), 'Much ado about two: Reconsidering retransformation and the tow-part model in health econometrics.', Journal of Health Economics 17(3), 247-281.

Pierce, J. P., C.Fiore, M., E.Novotny, T., Hatziandreu, E. J. and M.Davis, R. (1989), 'Trends in cigarette smoking in the united states. educational differences are increasing.', The Journal of the American Medical Association 261(1), 56-60.

Sloan, F. A. and G.Trogdon, J. (2004), 'The impact of the master settlement agreement on cigarette consumption.', J Policy Anal Manage 23(4), 843-855.

Suranovic, S. M., Goldfarb, R. S. and Leonard, T. C. (1999), 'An economic theory of cigarette addiction.', Journal of Health Economics 18(1), 1-29.

Tauras, J. A. (2004), 'Public policy and some-Âday smoking among adults.', Journal of Applied Economics 7(1), 137-162.

Tauras, J. A. (2005), 'An empirical analysis of adult cigarette demand.', Eastern Economic Journal 31(3), 361-375. 